\title{
Effect of Manpower and Resource Factors on Labor Productivity at House Building Projects in DHA Lahore
}

\author{
S. Mutahir Hussain Shah ${ }^{1, *} \mid$ Muhammad Nawaz $^{2} \mid$ Aimen Batool $^{3}$ \\ ${ }^{1}$ Institute of Business \& Management, University of Engineering and Technology, Lahore, Pakistan \\ ${ }^{2}$ National College of Business Administration e Economics, Lahore, Pakistan \\ ${ }^{3}$ Kinnaird College for Women University, Lahore, Pakistan \\ *Corresponding author: mutahir5@gmail.com
}

Received 27 May 2021; Revised 19 June 2021; Accepted 20 June 2021

\begin{abstract}
Construction industry suffers numerous issues and complicated factors like price, period, quality and safety. It is said that Construction projects are versatile because they associate with contractors, architects, advisers, designers, the project owners, etc. Keeping in view of above factors, objective of this research is to highlight those factors which have impact on labor productivity in house building project. Through literature review as well as discussion with different consultants, several factors of productivity were identified. Out of which 20 factors were selected, which were later categorized into two sets, for analyzing in the current study. A comprehensive questionnaire was prepared and sent to project manager, engineers, designers, and builders. It was found, that total expense of construction comes to much higher as it was originally calculated. It is suggested that human resource should be developed through an effective and well planned training program, so that construction project do not suffer due to low performance. The mentioned factors are supposed to help in completed the construction projects effectively.
\end{abstract}

Keywords: Productivity; Construction; Manpower factor; Resources factor

\section{Introduction}

In the past, number of studies were conducted for labor productivity in construction sector. Numerous of them were to analyze the effect of factors of productivity. This analysis and quantifiable calculation of these factors of productivity are essential for many purposes. It can be used for the calculation of project duration, its planning and forecasting. Previous studies reflect that it is very difficult to evaluate such impact. Also there is no globally recognized standard to evaluate the factors which result in the loss of labor productivity for construction sector. This deficiency of process of evaluating the effects of labor productivity emphasize the requirement to generate the quantifiable valuation for the factors which affect the productivity in construction sector. Hence this is the research topic.

These days the major issue for the organizations is to enhance their productivity, by converting the human resource into such a valuable commodity which can sell at a high rate and can earn high profit for the organization (Wilcox, 2000). Researchers have done significant effort to comprehend the 
concepts of productivity. This effort resulted in numerous definition of productivity (Karayalcin \& Pintea, 2015; Oglesby et al., 2002; Paulson, 1975).

\subsection{Productivity Defined}

The ratio of output volume to input is normally defined as Productivity. It can also be defined as the efficiency of labor used as input to produce certain level of output. Researchers say that perfect productivity, which is equal to one (1.0) can be attained if labor work for forty hours a week. They should avail all the due holidays. Work should not be delayed. There should not be any rework. Work safety has been the prime consideration. Weather condition should be optimum and no court case at the end of the project (Rowlinson \& Procter, 1999).

The link among output and input coined the term productivity (Liou \& Borcherding, 1986). This input and output varies from industry to industry. The definition of productivity will change with the change in location of the industry. The productivity of labor is normally determined by the expense incurred on labor to the work they performed (Liou \& Borcherding, 1986). The labor productivity as per Drewin, is defined as quantity of goods and services generated by the labor in a unit time (Drewin, 1982).

Littre defined productivity, in the year 1883, as a desire to produce (Jarkas, 2005). There is an Organization for European Economic Cooperation (OEEC), this organization has defined productivity in nineteen hundred and fifty, as a quotient gained as output divided by one of a production factors (Sumanth, 1984). Subject to dimension of purposes and accessibility of the data, numerous definitions of the productivity come across. The United States Department of Commerce has also defined productivity, as "numbers of dollars generated by one labor hour input" (Adrian, 1987).

\subsection{Productivity Importance}

Construction industry is labor and capital intensive. Hence in this industry it is very essential to emphasize on productivity. For the construction projects labor productivity establishes an important share of production input. There are numerous internal and external factors in construction sector which are not constant therefore it is not possible to identify them beforehand. Therefore due to this factor labor productivity varies continuously. Here it is important to ensure that plan, schedule, and work should not effect by decline in productivity, which result in delays. These delays result in losses of revenue. Therefore expenses can be reduced by enhancing the labor productivity. In this way lass number of workers can do the same job by enhanced productivity, resulting save cost and enhance revenue (Thomas, 1991).

\subsection{Problem Statement}

It has been observed that productivity has Decline in house building sector which is a biggest issues. Because of these field factors, the contracts of construction are deficient in classifying the productivity loss (CII, 2000; Hanna \& Haddad, 2009). Among different cost factors like men, material and equipment, the labor factor is generally the most risk bearing factor. The other two factors which are material and equipment do not impact much as their prices are market driven and not under the control of project manager. The estimated labor cost in any construction project is roughly 35 to 50 percent (Hanna et al., 2005). Since human resource is most unpredictable as compare to other cost factors, so it is essential to find out an effect of these factors on productivity of workers. This is also a well-known fact the labor expenses can be reduced by increasing the labor productivity. Hence it plays a very effective part in reducing the cost and increasing the profit in a construction sector (Hanna et al., 2005).

\subsection{Research Contribution}

This research contributes in investigating a very important and essential factor which directly affects the labor productivity. It is helpful to comprehend these factors for those persons who are responsible to complete the construction projects in time. The study will benefit the stakeholders associated with the house building in the housing societies like the Defense Housing Authorities (DHA), an affluent housing society with presence in multiple cities of Pakistan. The objective of this study is to make 
available those factors to project managers which are essential to complete the project successfully and cost effectively.

\section{Literature Review}

\subsection{Labor Productivity}

Before 1960 the productivity enhancement was evaluated for construction sector (Stall, 1983). After that it remains a global distress of decline in productivity in construction sector. To cater for this issue a Construction Forum was created in 1968. This forum was created because of issues due to enhanced construction cost, rise in rate of inflation, and considerably decrease of productivity in construction sector (Thomas \& Kramer, 1988). In 1965, the United Nations Committee on Housing, Building and Planning circulated an important handbook related to processes and operations of building construction (UNCHBP, 1965). It revealed that enhancement in productivity in construction sector is a dire need in comparison to other sectors. It was also required to adopt the knowledge of manufacturing sector to construction sector (Alarcon, 1991).

There are numerous factors which affect the productivity as revealed previous research. Even in advanced countries it is required to analyze for these unknown factors (Makulsawatudom \& Margaret, 2002). Polat and Arditi (2005) revealed that each country has different policies about enhancement of productivity. Different factors were recognized due to this research which has impact on labor productivity. These factors were grouped together as per their characteristics. Adrian (1987) categorized the factors of productivity which are responsible for the decline in productivity. Literature suggests that overtime schedule generally result in decline of efficiency since failure of in time delivery (Ginther, 1993).

The normal methods used in most of the studies related to productivity are interview and survey. In Singapore a survey was conducted for major construction companies to find out factors (Lim \& Alum, 1995). These factors have considerable effect on productivity. Following three issues were pointed out, trouble in hiring supervisor, trouble in hiring labor, and high attrition rate of labor. Portas and AbouRizk (1997) circulated questionnaire to project managers and supervisors to find out the factors which impact the productivity. The contractors and suppliers were interviewed, which revealed that delivery of material affect the productivity. The bad weather is also another feature affecting the productivity (Hassanein \& Melin, 1997).

Productivity is the resultant of numerous interrelated factors. From previous studies numerous factors were identified which affect the productivity of labor. These factors are discussed in the succeeding section.

\subsection{Identification of Factors Affecting Productivity}

This study revealed numerous factors from past studies that impact productivity of labor. The factors which were related are grouped. The factors which do not contain any significant value were dropped. Twenty sub-factors were identified and classified into the following two groups of factors:

2.2.1 Manpower Factor. This factor includes eight sub-factors; Absenteeism, Age, Alcoholism, Disloyalty, Lack of competition among workers, Lack of experience, Misunderstanding among laborers, and Personal problems.

2.2.2 Resource Factor. This factor includes twelve sub-factors; Differing site conditions from the plan, Insufficient construction method, Insufficient transport facilities for labors, Increase in the price of materials, Insufficient lighting, Non availability of required construction materials, Shortage of required equipment \& tools, Location of Material storage, Access to construction job site is not adequate, Poor site conditions, Quality of required work, and Violations of safety laws.

\section{Research Methodology}

Survey research method was adopted in the current study. It is defined as collecting data by sending a questionnaire to relevant persons (Enshassi et al., 2006). Questionnaires and personal interviews were 
the two methods applied for data collection. The most effective method used was the questionnaire which was preferred more due to the fact that it was designed according to the web and was selfadministered. It needs less time and money to create and the answer fills the questionnaire however they prefer. Unfortunately, this results in the estimate of answers given much lower in contrast to personal interviews.

\subsection{Survey Planning}

The questionnaires for the survey were sent through emails and the goal of the survey was to acquire general information about labor productivity in building construction at the Defense Housing Authority (DHA) Lahore and its multiple factors. To minimize inaccuracy in the survey, the respondents were informed beforehand of the purpose and the instructions to fill out the questionnaires. To make the procedure go smoothly, some supervision was provided throughout and to preserve confidentiality, the data collected through emails was reserved in raw data sheets.

\subsection{Considerations for the Survey}

Making the survey uncomplicated and easy to understand for the respondents was the principal aim due to the fact that dropout rate can be quite high if the questions are too challenging. The survey was extremely carefully curated in a way that the opening questions do not affect the result of the following questions negatively. In order to explain the project to the answerers, introductory content was supplied and questions that were logic based and could cause exasperation in the respondents were not included. The study was conducted to find any flaws and inadequacy in the questions and to make sure they were liable.

\subsection{Organization of the Questionnaire}

It was a largest concern to get back the completely and accurately filled questionnaires. The desire was to get back maximum number of filled forms. Previous studies were taken into consideration while inspecting the accuracy of this study. The fact that the respondents received the required time needed to precisely attempt and turn in the survey to the researcher online was given the utmost importance and the simplicity and understandability of the questions was assured. In total, the amount of the questionnaires distributed was 250 .

\section{Results and discussion}

\subsection{Data collection through surveying}

Collecting accurate and appropriate data is the main concern of any scientific study. From a defined population, the important data obtaining is an essential procedure (Bohrnstedt, 1994). The number of questionnaires sent to construction professionals via email was 250 and in return around 64 were filled out which resulted in 25.6 percent rate of replies (Table 1). Most often data missed as questionnaire filling person do not respond the questions properly (Kim, 1993). The amount of invalid data deleted altogether from the research was about 14 (i.e., 5.6\%), for the reason being that most of the data was either incomplete or inaccurate.

\subsection{Dimensions of collected data}

At different stages of house building there are number of troubles and risks affecting construction activities. To counter these threats, four situational grades were defined; (i) Not applicable, (ii) Not

Table 1. The questionnaire distribution

\begin{tabular}{|l|c|c|}
\hline & Number & Percentage \\
\hline Total questionnaires sent & 250 & 25.6 \\
\hline The questionnaires returned & 64 & 5.6 \\
\hline Invalid data & 14 & 20.0 \\
\hline Valid data for the study & 50 & \\
\hline
\end{tabular}


affective, (iii) Little bit affective, and (iv) Significantly affective. Such grading is not uncommon in literature. This grading helped the respondents to easily understand the different grades of risk levels and threats to house building projects. The elaborative questionnaire was constructed to be used as an instrument to compute the factors which are responsible to increase or decrease the labor productivity in a house building project.

To adopt the appropriate method for this study, the grades are to be evaluated. There is appropriate method for each grade. This study has adopted ordinal scale. Normally digits like 1-2-3-4 are used to define these grades. Here one can be lowest or highest grade, depending on the needs of the researcher. Normally these grades do not have equal weightage, and are generally are used for labeling purpose (Ugwu \& Haupt, 2007; Iyer \& Jha, 2005; Cheung et al., 2004).

\subsection{Analysis technique}

A procedure was formulated to analyse the collected data. The easy communication was established to make the process simple. Generally two methods are adopted to compute the data. Relative Importance Index (RII) was used to analyse data. It involves, (i) Grading the factors in ascending or descending order as per their degree of risk followed by computation of RII against each factor, and (ii) Later categorizing the grades as significant or not. Different researchers has successfully used RII for analyzing productivity factors in house building projects (see, e.g., Ugwu \& Haupt, 2007; Iyer \& Jha, 2005; Cheung et al., 2004). Also, it has seen application on Pakistani construction projects as well (Sheikh et al., 2019). RII can be calculated as:

$$
\mathrm{RII}=\frac{\sum W}{A \times N}
$$

where, $W=$ number 1 - 4 marked by persons on questionnaire, $A=$ the maximum value on the scale, which is 4 in our case, and $N=$ total number of responses.

\subsection{Manpower factors affecting worker productivity}

For the manpower group, various factors for their ranking are shown in Table 2. With an RII value of 475, the manpower factor of lack of experience topped the list.

Productivity is greatly influenced by lack of experience of labor. Paulson has evaluated the consequences faced by the workers and its effect on labor productivity (Paulson, 1975). This deduction is also reinforced by Heizer and Render (1990) who confirmed that the work site productivity is influenced by the skills and awareness of the workers. Thus, one may argue that as a result of the skills, productivity of labor is likely to increase.

\subsection{Resource factors affecting worker productivity}

Group of resource factors is shown in Table 3. With an RII value of 557, the construction material shortage is at $1^{\text {st }}$ position.

Table 2. The group of manpower factors

\begin{tabular}{|l|c|c|}
\hline \multicolumn{1}{|c|}{ Manpower Factors } & RII & Rank \\
\hline Inadequate experience & 475 & 1 \\
\hline Absenteeism & 467 & 3 \\
\hline Misunderstanding among laborers & 436 & 4 \\
\hline Age & 422 & 5 \\
\hline Lack of competition among the laborers & 412 & 6 \\
\hline Alcoholism/drugs & 359 & 7 \\
\hline Disloyalty & 348 & 8 \\
\hline Personal problems & 338 & \\
\hline
\end{tabular}


As per Kini (1999), the material resource make out about 40 to 60 percent of total value of house building project. It is evaluated from old studies that impact of material management on labor productivity was not given due consideration. Without the necessary materials needed for a particular task, it is impossible to complete it. In different past studies this factor was places at first position in different countries (Lim \& Alum, 1995; Guhathakurta, 1993; Olomolaiye, 1987). Materials that are beyond reach or need a long time to acquire is known as a lack of material. Thomas et al. (1999) evaluated that lack of material management about 18 percent of work-hour are to be done extra. Material unattainability resulted in 35.6 hours of unproductive time; hence, $9.5 \%$ of wasted time in total.

With an RII of 539, non-availability of construction equipment is placed at $2^{\text {nd }}$ place. For construction procedure the accessibility of tools is necessary. Factors that affect labor productivity is the lack of tools in most cases, also shown in previous studies (see, Guhathakurta, 1993; Olomolaiye, 1987).

With an RII of 503, the location of material storage is placed at number $6^{\text {th }}$ position among resource group. Sanders and Thomas (1991) argued that construction material storage size and location has a considerable effect on the productivity of the workers.

With an RII of 509, inadequate lighting is placed at third position.

A not proper approach to the construction site is placed at $7^{\text {th }}$ position having RII 489. Sanders and Thomas (1991) also reported similar fact.

With an RII of 489, inadequate access in a construction site has got $7^{\text {th }}$ place among resource group. Sanders and Thomas (1991) verifies that inadequate access to constriction site is a cause of low workers' productivity.

With an RII of 485, not following the safety laws was placed at eighth position. House building construction is considered to be among extreme unsafe industrial sectors (Suazo \& Jaselskis, 1993). Some of the main reasons that cause accidents is human behaviour, the distinctive nature in housing project, construction location situation etc. These situations are difficult and result in poor safety management. It often jeopardizes the working process, work equipment and work process. Among employees and employers, the main objective should be to minimize occupational injuries and illnesses. Working environment tends to change regularly which increases risks in the construction industry. When a hazard id identified in any construction site and it is managed properly, then it is very likely that a new hazard may emerge within no time (Davies \& Tomasin, 1990).

In the resource group $9^{\text {th }}$ rank was given to the quality of work with an RII value of 479 . Often rework is required since the quality of the product is not up to mark. Cheung et al. (2004) argued that job quality will always have an impact on the quality of work. Iyer and Jha (2005) has analysed that quality of douing s job has always an impact on the cost management of the house building. The three main constrictions are quality, cost, time.

The lack of transportation facility for labors is placed at $10^{\text {th }}$ with RII of 437. Past studies (Karayalcin \& Pintea, 2015; Harriet et al., 2013) confirm that lack of transport facility has impacted on the labor

Table 3. The group of resource factors

\begin{tabular}{|l|l|l|}
\hline \multicolumn{1}{|c|}{ Resource Factors } & RII & Rank \\
\hline Deficiency of required construction material & 557 & 1 \\
\hline Deficiency of required construction equipment /tools & 539 & 2 \\
\hline Inadequate lighting & 509 & 3 \\
\hline Site condition not appropriate & 509 & 4 \\
\hline Site condition not as per plan & 503 & 5 \\
\hline Location of Material storage & 503 & 6 \\
\hline Access to construction job site is not adequate & 489 & 7 \\
\hline Safety laws Violation & 485 & 8 \\
\hline Required work quality & 479 & 9 \\
\hline Insufficient transport facilities for labors & 437 & 10 \\
\hline Insufficient construction material & 436 & 11 \\
\hline Rise in the price of material & 395 & 12 \\
\hline
\end{tabular}


productivity. It is difficult for the workers to reach the construction site if it is located outside the city or no transport goes to that place.

\section{Conclusion and recommendations}

\subsection{Conclusions}

Construction sector is known as number one sector which play a pivotal role to boost the economic conditions of a nation. It is very essential to have a thorough understanding about construction work and labor productivity, as it will save cost and reduce rework. Since construction projects at time are complicated and require huge investment. Hence there are numerous factors which have impact on the projects construction process also the labor productivity may get affected. This leads to late completion pf project, result in incur more finances as it were planned.

This particular research work emphasizes to identify the factors involved to reduce the productivity of labor. The data collected was analyzed, as the goal of this research was to evaluate those factors which have impact on labor Productivity in labor intensive house building sector. Relative Important Index (RII) was used to calculate the factors ranking.

\subsection{Recommendations and future directions}

Collecting The progress of building projects hampered because of litigation and conflicts, more over they are costly projects. To successfully complete the project construction companies should keep the atmosphere conducive. It is also very important to identify the risks and flaws of the project so that they could be managed well in time. To improve labor productivity few points are listed below.

i. Material supply schedule be prepared for timely availability of building material from the market.

ii. Light should be adequate to avoid work injuries and accidents.

iii. Safety training should be periodically given to workers.

iv. Material should be placed near to construction site so that provision of material to workers should be in minimum time.

v. Plan should be there to select best worker of the month.

vi. Monitory benefit can be given to best worker.

vii. An atmosphere of competition can be created at the construction site.

viii. There should be periodical drug test of the workers and penalize those who found positive.

ix. The workers may be provided transport facility if construction site at remote area.

x. Workers presence can be enhanced by providing them paid off time and holidays.

This research is confined to the construction of house buildings in the DHA Lahore. Further study can be conducted in other regions and housing societies. It can also be done for different type of buildings like, educational buildings, commercial plaza, high-rise buildings etc. It can also be done for other sectors like transportation, which include roads and bridges.

\section{References}

Adrian, J. (1987). Construction Productivity Improvement. Amsterdam, Netherlands: Elsevier Science Publishing.

Alarcon, L. F. (1991). Quantitative effects on construction productivity. The Construction Lawyer, American Bar Association.

Bohrnstedt, G. W., \& Knoke, D. (1994). Statistics for Social Data Analysis (3 ${ }^{\text {rd }}$ Ed.). Itaska IL: F E Peacock Publishers Inc.

Cheung, S. O., Suen, H. C. H., \& Cheung, K. K. W. (2004). PPMS: A web-based construction project performance monitoring system. Automation in Construction, 13(3), 361-376. https://doi.org/10.1016/j.autcon.2003.12.001

CII. (2000). RS158-1 - Quantiffing the Cumulative Impact of Change Orders for Electrical and Mechanical Contractors. Cumulative Change Order Impact Research Team, Construction Industry Institute (CII), University of Texas at Austin.

Davies, V. J., \& Tomasin, K. (1990). Construction Safety Handbook. London: Thomas Telford Ltd.

Drewin, F. J. (1982). Construction Productivity: Measurement and Improvement through Work Study. NewYork: Elsevier Science Ltd. 
Enshassi, A., Al-Hallaq, K., \& Mohamed, S. (2006). Causes of contractors' business failure in developing countries: The case of Palestine. Journal of Construction in Developing Countries, 11(2), 1-14.

Ginther, R. S. (1993). The effect of work environment on labor performance. ME thesis, Pennsylvania State University, University Park, PA.

Guhathakurta, S., \& Yates, J. (1993). International labor productivity. Journal of Construction Engineering, 35(1), 1525.

Hanna, A. S., \& Haddad, G. (2009). Overtime and Productivity in Electrical Construction. Proceedings of the Construction Research Congress 2009, held in April 5-7, 2009 in Seattle, Washington. https://doi.org/10.1061/41020(339)18

Hanna, A. S., Taylor, C. S., \& Sullivan, K. T. (2005). Impact of extended overtime on construction labor productivity. Journal of Construction Engineering and Management, 131(6), 734-740. https://doi.org/10.1061/(ASCE)0733-9364(2005)131:6(734)

Harriet, T., Poku, K., \& Emmanuel, A. K. (2013). An Assessment of Traffic Congestion and Its Effect on Productivity in Urban Ghana. International Journal of Business and Social Science, 4(3), 225-234.

Hassanein, A., \& Melin, J., (1997). Crew design methodology for construction contractors. Journal of Construction Engineering and Management, 123(3), 203-207. https://doi.org/10.1061/(ASCE)0733-9364(1997)123:3(203)

Heizer, J., \& Render, B. (1990). Production and Operations Management. Strategic and Tactical Decisions. NJ: Prentice Hall.

Iyer, K. C., \& Jha, K. N. (2005). Factors affecting cost performance: Evidence from Indian construction projects. International Journal of Project Management, 23, 283-295. https://doi.org/10.1016/j.ijproman.2004.10.003

Jarkas, A. M. (2005). An investigation into the influence of build-ability factors on productivity of in situ reinforced concrete construction. Ph.D. thesis, University of Dundee, Dundee, UK.

Karayalcin, C., \& Pintea, M. (2015). The Role of Productivity, Transportation Costs, and Barriers to Intersectoral Mobility in Structural Transformation. IMF Working Paper No. WP/15/91. International Monetary Fund.

Kim, D. H. (1993). The link between individual and organizational learning. Sloan Management Review, Fall, 37-50.

Kini, D. U. (1999). Materials management: The key to successful project management. Journal of Management in Engineering, 15(1), 30-34. https://doi.org/10.1061/(asce)0742-597x(1999)15:1(30)

Lim, E. C., \& Alum, J. (1995). Construction productivity: Issues encountered by contractors in Singapore. International Journal of Project Management, 13(1), 51-58. https://doi.org/10.1016/0263-7863(95)95704-H

Liou, F. S., \& Borcherding, J. D. (1986). Work sampling can predict unit rate productivity. Journal of Construction Engineering and Management, 112(1), 90-103. https://doi.org/10.1061/(ASCE)0733-9364(1986)112:1(90)

Makulsawatudom, A., \& Margaret, E. (2002). Critical factors influencing construction productivity in Thailand. In: Proceedings of the $10^{\text {th }}$ International CIB Symposium of the W65 Commission on Organisation and Management of Construction: Construction Innovation and Global Competitiveness. University of Cincinnati; 2002. p. 1446-1456.

Oglesby, C. H., Parker, H. W., \& Howell, G. A. (2002). Productivity Improvement in Construction. New York: McGrawHill.

Olomolaiye, P. O., Wahab, K. A., \& Price, A. D. F. (1987). Problems influencing craftsman's productivity in Nigeria. Building Environment, 22(4), 317-323.

Paulson, B. C. (1975). Estimation and control of construction labor costs. Journal of the Construction Division, 101(3), 623-633.

Polat, G., \& Arditi, D. (2005). The JIT Management System in developing countries. Construction Management and Economics, 23(7), 697-712. https://doi.org/10.1080/01446190500041388

Portas, J., \& AbouRizk, S. (1997). Neural network model for estimating construction productivity. Journal of Construction Engineering and Management, 123(4), 399-410. https://doi.org/10.1061/(ASCE)07339364(1997)123:4(399)

Rowlinson, M., \& Procter, S. (1999). Organizational Culture and Business History. Organization Studies, 20(3), 369 396. https://doi.org/10.1177/0170840699203001

Sanders, S. R., \& Thomas, H. R. (1991). Factors affecting masonry productivity. Journal of Construction Engineering and Management, 117(4), 626-644. https://doi.org/10.1061/(ASCE)0733-9364(1991)117:4(626)

Sheikh, A. H. A., Ikram, M., Ahmad, R. M., Qadeer, H., \& Nawaz, M. (2019). Evaluation of key factors influencing process quality during construction projects in Pakistan. Grey Systems: Theory and Application, 9(3), 321-335. https://doi.org/10.1108/GS-01-2019-0002

Stall, M. D. (1983). Analyzing and improving productivity with computerized questionnaires and delay surveys. Project Management Quarterly, 14(4), 69-79.

Suazo, G. A. R., \& Jaselskis, E. J. (1993). Comparison of construction safety codes in the United States and Honduras. Journal of Construction Engineering and Management, 119(3), 560-572. https://doi.org/10.1061/(ASCE)0733-9364(1993)119:3(560)

Sumanth, D. J. (1984). Productivity Engineering and Management. New York: McGraw-Hill.

Thomas, H. R. (1991). Labor productivity and work sampling: The bottom line. Journal of Construction Engineering and Management, 117(3), 423-444. https://doi.org/10.1061/(ASCE)0733-9364(1991)117:3(423) 
Thomas, H. R., \& Kramer, D. F. (1988). The manual of construction productivity measurement and performance evaluation. Source Document 35, Construction Industry Institute, The University of Texas at Austin.

Thomas, H. R., Riley, D. R., \& Sanvido, V. E. (1999). Loss of labor productivity due to delivery methods and weather. Journal of Construction Engineering and Management, 125(1), 39-46. https://doi.org/10.1061/(ASCE)0733-9364(1999)125:1(39)

Ugwu, O. O., \& Haupt, T. C. (2007). Key performance indicators and assessment methods for infrastructure sustainability-A South African construction industry perspective. Journal of Engineering Design and Technology, 42(2), 665-680. https://doi.org/10.1016/j.buildenv.2005.10.018

UNCHBP. (1965). Effect of repetition on building operations and processes on site: report of an enquiry undertaken by the Committee on Housing, Building and Planning. United Nations, New York, NY. Retrieved from https://digitallibrary.un.org/record/780356

Wilcox, S., Stringfellow, B., Harris, R., and Martin, B. (2000). Management and Productivity. Transportation Research Board, Committee on Management and Productivity, Washington, DC. 